\title{
Comparative Virus Resistance and Fruit Yield of Transgenic Squash with Single and Multiple Coat Protein Genes
}

\author{
Marc Fuchs, Department of Plant Pathology, Cornell University, New York State Agricultural Experiment Station, \\ Geneva 14456; David M. Tricoli and Kim J. Carney, Asgrow Seed Company, Kalamazoo, MI 49002; Mike \\ Schesser, Hobart and William Smith Colleges, Department of Biology, Geneva, NY 14456; James R. McFerson, \\ USDA-ARS, Plant Genetic Resources Unit, Cornell University, Geneva, NY 14456; and Dennis Gonsalves, De- \\ partment of Plant Pathology, Cornell University, New York State Agricultural Experiment Station
}

\begin{abstract}
Fuchs, M., Tricoli, D. M., Carney, K. J., Schesser, M., McFerson, J. R., and Gonsalves, D. 1998. Comparative virus resistance and fruit yield of transgenic squash with single and multiple coat protein genes. Plant Dis. 82:1350-1356.

Five transgenic squash lines expressing coat protein $(\mathrm{CP})$ genes from cucumber mosaic cucumovirus (CMV), zucchini yellow mosaic potyvirus (ZYMV), and watermelon mosaic virus 2 potyvirus (WMV 2) were analyzed in the field for their reaction to mixed infections by these three viruses and for fruit production. Test plants were exposed to natural inoculations via aphids in trials simulating the introduction of viruses by secondary spread from mechanically infected susceptible border row plants. Plants of transgenic line CZW-3 expressing the CP genes from CMV, ZYMV, and WMV 2 displayed the highest level of resistance with no systemic infection, although $64 \%$ exhibited localized chlorotic dots which were mainly confined to older leaves. CZW-3 plants had a 50-fold increase in marketable yield compared to controls and the highest predicted cash returns. Plants of transgenic line ZW-20 expressing the CP genes from ZYMV and WMV 2 displayed high levels of resistance to these two potyviruses, but $22 \%$ became infected by CMV. However, ZW-20 plants provided a 40 -fold increase in marketable yield relative to controls and good estimated cash returns. Three transgenic lines expressing single $\mathrm{CP}$ genes from either ZYMV (line Z-33), WMV 2 (line W-164) or CMV (line C-14) developed systemic symptoms similar to those of controls but showed a delay of 2 to 4 weeks before the onset of disease. Plants of transgenic line Z-33 were highly resistant to ZYMV but not to WMV 2 and CMV. Interestingly, Z-33 plants had a 20 -fold increase in marketable yield compared to controls and some predicted cash returns if market sale prices were high. This study indicates that virus-resistant transgenic lines are economically viable even if they are affected by viruses other than those to which they are resistant.
\end{abstract}

Additional keywords: epidemiology, pathogen-derived resistance, profitability

Squash (Cucurbita pepo L.) is affected worldwide by several viral diseases that substantially reduce yield and fruit quality. Four of the most important viruses that affect squash production are cucumber mosaic cucumovirus (CMV), zucchini

Corresponding author: Dennis Gonsalves E-mail: dg12@cornell.edu

Current address of first author: INRA, Unité de Recherches Vigne et Vin, Laboratoire de Pathologie Végétale, 28 rue de Herrlisheim, 68021 Colmar, France.

This research was supported in parts by grants (No 92-39210-8261 and 95-33120-1878) from the USDA Biotechnology Risk Assessment Program awarded to D. Gonsalves and M. Fuchs in 1992 and 1995, respectively. M. Schesser was supported by a fellowship from the Undergraduate Biological Sciences Education program of the Howard Hughes Medical Institute.

Accepted for publication 4 September 1998.

Publication no. D-1998-1019-01R

(C) 1998 The American Phytopathological Society give good production of marketable fruit under conditions where viruses were not deliberately introduced (3), as well as under conditions of single $(6,18)$ or mixed infections $(6,10,18)$.

In 1994, the cultivar Freedom II, a yellow crookneck summer squash hybrid, produced with transgenic inbred line ZW20 as one parent, became the first virusand disease-resistant transgenic crop to be deregulated in the United States (14). 'Freedom II' was commercialized in 1995. Summer squash hybrids using transgenic line CZW-3, resistant to CMV, ZYMV, and WMV 2, as a parent (18) will soon be commercialized (1). Fruit yield and plant reaction to single and mixed infections by CMV, ZYMV, and WMV 2 have been reported for transgenic line CZW-3 $(3,6,18)$. However, reaction to mixed infections by CMV, ZYMV, and WMV 2, with virus spread mediated by aphid vectors has not been extensively studied.

Mixed infections are often detected in squash fields $(2,7,16,19)$. More than 20 viruses have been reported worldwide in the major squash-growing areas $(5,8,15,22)$. Although it is likely that virus resistance will be developed for the major viruses affecting production, the development of resistance to all, or most, viruses infecting squash is unlikely to be achieved. Also, the restricted geographical distribution and the limited impact of some of them do not favor the development of cultivars with resistance to viruses with limited economical importance. Thus, it appears that squash cultivars with resistance to fewer viruses than those present in a particular region will be used. Our study addresses the question of economic viability of cultivars that are resistant to a limited number of viruses. In other words, can transgenic squash with resistance to a limited number of viruses provide a profitable yield when the crop is affected by viruses other than those to which they are resistant?

In this study, we compare the level of virus resistance and the fruit yield of five selected transgenic squash lines expressing either triple (line CZW-3), double (line ZW-20), or single (lines Z-33, W-164, and C-14) CP gene constructs under conditions of severe aphid inoculation pressure of CMV, ZYMV, and WMV 2. 


\section{MATERIALS AND METHODS}

Plant material. Virus-resistant transgenic squash plants used in this study were developed by Asgrow Seed Company as described previously (18). Briefly, transgenic squash plants expressing $\mathrm{CP}$ genes were obtained by Agrobacterium tumefaciens-mediated transformation. Expression of each $\mathrm{CP}$ gene was driven by the cauliflower mosaic virus (CaMV) $35 \mathrm{~S}$ promoter, part of the intergenic region of RNA 3 of CMV strain $\mathrm{C}$ used as leader sequence, and the nopaline synthase or the $\mathrm{CaMV} 35 \mathrm{~S}$ was used as terminator sequences (18).

Seeds of transgenic and non-transgenic squash lines were supplied by Asgrow Seed Company, and subsequent greenhouse and field work were performed at Cornell University. We selected five transgenic lines and three non-transgenic control genotypes. The five transgenic lines were: Pavo CZW-3 (CZW-3), expressing the CP genes of CMV strain C, ZYMV strain FL, and WMV 2 strain FL; Pavo ZW-20B (ZW-20), expressing the CP genes of ZYMV strain FL and WMV 2 strain FL; YC Z-33 (Z-33), expressing the CP gene of ZYMV strain FL; Dixie W-164 (W-164), expressing the $\mathrm{CP}$ gene of WMV 2 strain FL; and Pavo C-14 (C-14), expressing the $\mathrm{CP}$ gene of CMV strain $\mathrm{C}$. The three nontransgenic control genotypes were Asgrow's proprietary hybrids Pavo and Dixie, and the inbred line YC.

Identification of transgenic plants and mechanical inoculations. Seeds were germinated in artificial soil medium. Transgenic seedlings of segregating lines were identified by enzyme-linked immunosorbent assay (ELISA) for the expression of the marker gene neomycin phosphotransferase (NPT II) using commercial $\gamma$-globulins as reported (10). Mechanical inoculations were carried out as described previously on 10-day-old seedlings showing one fully expanded leaf and a second emerging (10), except for C-14 and CZW-3 plants. Plants of transgenic line C-14 were inoculated with a 1:50 dilution (wt:vol) of crude sap of CMV-infected squash cv. President. Plants of transgenic line CZW-3 were inoculated with a 1:15 dilution (wt:vol) of crude sap prepared from squash cv. President infected by either CMV, ZYMV, or WMV 2, with infected tissue from each of the three viruses mixed together and applied as a single inoculum. The inocula which consisted of CMV strain Fny, ZYMV strain FL, and WMV 2 strains Rob or NY were prepared in phosphate buffer (10). After mechanical inoculations, plants were maintained for 1 week in a screenhouse before field planting.

Field trials and experimental designs. Field experiments were conducted under Animal and Plant Health Inspection Services (APHIS)-United States Department of Agriculture permits, and were designed to compare the level of virus resistance and the fruit yield of several transgenic lines subject to mixed infections by CMV, ZYMV, and WMV 2. In the 1993 trial, we compared the reaction of four transgenic lines, three containing single $\mathrm{CP}$ genes (Z33, W-164, and C-14), and one containing three CP genes (CZW-3). Virus infections were achieved by mechanical and aphid inoculations. Approximately half of the plants, transgenic and controls, were rubinoculated and all of them were exposed to natural infection via vectors. Limited information was available on aphid flights; therefore, mechanical inoculations were performed for resistance evaluation in case aphids were not abundant. A complete block design was used with genotypes randomly assigned within each of four blocks and treatments (uninoculated versus mechanically inoculated plants) randomly imposed on genotypes. Additionally, mechanically inoculated spreader plants of the cv. Pavo, which are susceptible to the three test viruses, were transplanted at regular positions throughout the field ( 2 plants per block for each virus) to facilitate a uniform distribution of CMV, ZYMV, and WMV 2.

In the 1995 trial, we compared the effect of aphid-vectored mixed infections on three transgenic lines, one containing three $\mathrm{CP}$ genes (CZW-3), one containing two CP genes (ZW-20), and one with a single $\mathrm{CP}$ gene (Z-33). Line CZW-3 was selected because it is highly resistant to CMV, ZYMV, and WMV 2, whereas line Z-33 performed best in 1993 from those expressing single $\mathrm{CP}$ genes. Line $\mathrm{ZW}-20$ had previously displayed high levels of resistance to mixed infections by ZYMV and WMV 2 (10). Since the three non-transgenic genotypes (Pavo, Dixie, and YC) showed identical reaction in 1993, only Pavo was chosen as the control in 1995. Two experiments were conducted in locations $30 \mathrm{~m}$ apart, using a complete block design. Each experiment consisted of four blocks with genotypes randomly assigned within each block. The initial virus source came from a single border row of virus susceptible plants of the cv. Pavo that surrounded the experimental plot. The border plants were mechanically inoculated singly with either CMV, ZYMV, or WMV 2.

No insecticides were used, but fungicides were applied in both trials.

Evaluation of virus resistance, fruit yield, and estimated profit. The resistance of the transgenic lines to virus infection was evaluated for both trials by assessing symptoms every 3 to 5 days. In addition, leaves sampled at three or four different dates throughout the growing season were tested for infection by CMV, ZYMV, and WMV 2 by ELISA as described earlier $(10,12)$. Tissue from apical leaves in positions 1 to 5 were collected and stored at $-20^{\circ} \mathrm{C}$ until processed, as described previously $(10,12)$. All plants were sampled for both trials.
Fruit were visually rated in the field for virus symptoms and marketable size. Fruit with discoloration, green dots or stripes, and distortion, as well as culls, were scored as unmarketable. To determine if latent infections occurred in fruit of transgenic plants, the presence of viruses in fruit was determined in 1993 in a few randomly collected fruit by host indexing, as described previously (10). In 1995, fruit were harvested over 7 weeks, approximating commercial harvest practices. Fruit were counted, weighed, and scored for virus symptoms.

A relative cost-benefit analysis was carried out to assess the economical return of the transgenic lines (20). Predicted cash returns were evaluated as expected returns minus total costs. Total costs for equipment (tractor, plow, disk, cultivator, and sprayer), preharvest (picking and hauling), and postharvest (packing and marketing), were considered to be the same among transgenic lines. Also, the expected market price for marketable fruit was considered to be the same among transgenic lines. Thus, fruit yield and seed cost were the only variables in our cost-benefit analysis.

Data were subject to analysis of variance (ANOVA), and the mean responses were compared using SAS. Helmert contrasts were used to assess the significance of the differences over time.

\section{RESULTS}

Comparative virus resistance of transgenic lines CZW-3, Z-33, W-164, and C-14. The 1993 field trial focused on comparing the resistance of a transgenic line containing three $\mathrm{CP}$ genes (CZW-3) with three transgenic lines containing a single CP gene (Z-33, W-164, and C-14). Half of the test plants were mechanically inoculated and all of them were exposed to natural aphid-vectored inoculations. The four transgenic lines tested were segregating for the presence of the transgenes; thus, transgenic segregants were identified for the expression of the NPT II enzyme by ELISA prior to transplanting. We found a 1:1 segregation ratio with 60,294 , and 182 seedlings of lines CZW-3, W-164, and C14 , respectively. This segregation ratio was expected, because the three lines resulted from crosses of a transgenic line hemizygous for the NPT II and CP transgenes with a non-transgenic parent. A 3:1 segregation ratio was obtained for line Z-33 with 327 seedlings. Line Z-33 was derived from self-pollination of a line that was hemizygous for the NPT II and CP transgenes.

Visual monitoring of systemic virus symptoms over time was used to assess the resistance of plants to virus infection. Overall, uninoculated and mechanically inoculated plants reacted similarly, except that mechanically inoculated plants developed symptoms 1 to 2 weeks earlier than plants that were not mechanically inocu- 
lated, as described previously for some of the lines tested (10). Control plants first showed systemic foliar symptoms (consisting of mosaic, shoestringing, and downward curling) or plant stunting at 12 days post-transplanting (dpp), and all were symptomatic by $33 \mathrm{dpp}$, indicating efficient virus transmissions via vectors. In contrast, plants of transgenic line CZW-3 did not develop typical leaf or fruit symptoms. However, $73 \%$ of the CZW-3 plants showed localized chlorotic dots by the end of the growing season (68 dpp). These chlorotic dots were found mainly on older leaves and were similar to those described previously on transgenic ZW-20B plants (10), except that blotches were not observed. Moreover, the chlorotic dots also were observed on plants that were mechanically inoculated and those that were not mechanically inoculated.

The three transgenic lines with single CP genes (Z-33, W-164, and C-14) developed systemic foliar symptoms similar to those of controls. Symptoms observed on transgenic plants with single $\mathrm{CP}$ genes generally were less pronounced early in the season than those observed on controls, but no differences were apparent at the end of the season. However, the three lines with single CP genes showed a delay in symptom development compared to controls. Plants of transgenic line Z-33 exhibited a 3 -week delay in the onset of disease compared to controls, but all showed systemic symptoms by $57 \mathrm{dpp}$. Plants of transgenic lines W-164 and C-14 displayed a 1- to 2week delay in symptom development compared to controls, with nearly all becoming symptomatic by $48 \mathrm{dpp}$.
Plants were tested by ELISA at 32, 52, and $65 \mathrm{dpp}$ to identify the specific virus or viruses causing symptoms and to distinguish between single and mixed-virus infections. The cumulative ELISA data obtained at the end of the growing season (65 dpp) are indicated in Table 1 . Only $6 \%$ of the plants of transgenic line CZW-3 reacted positively in ELISA. ELISA-positive reactions were obtained for leaf tissue with chlorotic dots but not for asymptomatic leaf tissue. In contrast, 97 to $100 \%$ of the plants of transgenic lines with single CP genes and controls were ELISA positive. Plants of transgenic lines Z-33 and W-164 showed a substantially reduced incidence of mixed infections (26 and $43 \%$ for Z-33 and $\mathrm{W}-164$, respectively) compared to controls $(95 \%)$. On the other hand, plants of transgenic line C-14 showed $97 \%$ mixed infections. All cases of mixed infection were predominantly caused by ZYMV and WMV 2 (Table 1).

All fruit from CZW-3 plants were symptomless (Fig. 1A) and viruses were not recovered from them by indexing, indicating that latent infections did not occur in these fruit. In contrast, all fruit tested from transgenic plants with single CP genes and from control plants had symptoms (Fig. 1C and D). Yield data were not taken because growing conditions were poor in 1993 due to late transplanting and heavy rain falls.

ANOVA was used to determine which factor most influenced the variations in symptom development and virus incidence observed among lines. Results revealed that genotype was the only significant factor $(P<0.001)$. The inoculation method (mechanical versus aphid) and the interac- tion between genotype and inoculation method were not significant. Also, blocking had no effect. In addition, analysis of data by Helmert contrasts over time indicated that differences among genotypes were significant throughout the season $(P$ $<0.001)$.

Comparative virus resistance and fruit production of transgenic lines CZW-3, ZW-20, and Z-33. In the 1995 field trial, we compared virus resistance and fruit production of transgenic lines with three (CZW-3), two (ZW-20), and one (Z-33) CP gene under natural mixed infections by CMV, ZYMV, and WMV 2 . Transgenic segregants of line Z-33 were identified based on the expression of the NPT II protein, as determined by ELISA, and the expected 3:1 segregation ratio was obtained with 278 individuals analyzed. Transgenic lines CZW-3 and ZW20 were not analyzed similarly because they resulted from a cross between a transgenic hybrid homozygous for the NPT II and CP genes and a non-transgenic inbred parent.

Unlike the 1993 trial, plants in the 1995 trial were not mechanically inoculated. Instead, virus source plants were transplanted in a single border row to simulate natural conditions of infection in commercial plantings, where viruses are transmitted into the crop via aphids from surrounding virus-infected weeds or other hosts. Resistance was assessed by observing plants for virus symptoms and by testing leaf samples for specific viruses by ELISA. Two experiments were conducted in separate locations. Since no significant difference was observed between the two

Table 1. Enzyme-linked immunosorbent assay (ELISA) detection of cucumber mosaic cucumovirus (CMV), zucchini yellow mosaic potyvirus (ZYMV), and watermelon mosaic virus 2 potyvirus (WMV 2) in squash lines after field infections by CMV, ZYMV, and WMV 2 during the 1993 growing season

\begin{tabular}{|c|c|c|c|c|c|c|c|c|c|c|}
\hline \multirow[b]{2}{*}{ Genotypes $^{b}$} & \multirow[b]{2}{*}{ No. plants } & \multirow[b]{2}{*}{ Treatment } & \multicolumn{8}{|c|}{ Percent ELISA-positive plants ${ }^{a}$} \\
\hline & & & Total & $\mathbf{C}$ & $\mathbf{Z}$ & $\mathbf{W}$ & $\mathbf{C Z}$ & CW & $\mathbf{Z W}$ & CZW \\
\hline \multicolumn{11}{|c|}{ Transgenic lines } \\
\hline \multirow{2}{*}{ Pavo CZW-3 } & 17 & uninoculated & 6 & 0 & 0 & 6 & 0 & 0 & 0 & 0 \\
\hline & 16 & inoculated $\mathrm{C}+\mathrm{Z}+\mathrm{W}$ & 6 & 0 & 0 & 0 & 0 & 0 & 6 & 0 \\
\hline \multirow[t]{2}{*}{ YC Z-33 } & 39 & uninoculated & 100 & 0 & 0 & 78 & 0 & 9 & 13 & 0 \\
\hline & 41 & inoculated Z & 97 & 1 & 0 & 66 & 0 & 1 & 23 & 6 \\
\hline \multirow[t]{2}{*}{ Dixie W-164 } & 52 & uninoculated & 100 & 0 & 55 & 0 & 0 & 0 & 31 & 14 \\
\hline & 60 & inoculated W & 100 & 0 & 59 & 0 & 1 & 0 & 32 & 8 \\
\hline \multirow[t]{2}{*}{ Pavo C-14 } & 37 & uninoculated & 100 & 0 & 0 & 0 & 0 & 0 & 79 & 21 \\
\hline & 38 & inoculated C & 100 & 0 & 6 & 0 & 3 & 0 & 73 & 18 \\
\hline \multicolumn{11}{|c|}{ Non-transgenic lines } \\
\hline \multirow[t]{2}{*}{ Pavo } & 54 & uninoculated & 100 & 0 & 7 & 1 & 0 & 1 & 75 & 16 \\
\hline & 57 & inoculated C & 100 & 2 & 0 & 0 & 13 & 0 & 62 & 23 \\
\hline \multirow[t]{2}{*}{ YC } & 42 & uninoculated & 100 & 0 & 3 & 0 & 1 & 0 & 83 & 13 \\
\hline & 41 & inoculated Z & 100 & 0 & 3 & 2 & 0 & 0 & 77 & 18 \\
\hline \multirow[t]{2}{*}{ Dixie } & 53 & uninoculated & 100 & 0 & 5 & 0 & 2 & 0 & 81 & 12 \\
\hline & 53 & inoculated $\mathrm{W}$ & 100 & 0 & 7 & 0 & 2 & 0 & 77 & 14 \\
\hline
\end{tabular}

${ }^{a}$ Data represent cumulative percent of ELISA-positive plants for CMV (C), ZYMV (Z), WMV 2 (W), CMV + ZYMV (CZ), CMV + WMV 2 (CW), ZYMV + WMV 2 (ZW), and CMV + ZYMV + WMV 2 (CZW) on 24 September (65 days post transplanting). Infected leaf samples had optical density (OD) $405 \mathrm{~nm}$ readings 5 to 45 times higher than those of healthy plants ( 0.135 to 1.250 versus 0.027 to 0.040 for CMV, 0.320 to 1.750 versus 0.029 to 0.038 for ZYMV, and 0.115 to 0.560 versus 0.015 to 0.025 for WMV 2) after $60 \mathrm{~min}$ substrate hydrolysis. Noninfected transgenic plants had OD $405 \mathrm{~nm}$ values of 0.069 for CMV (lines C-14 and CZW-3), 0.056 for ZYMV (lines Z-33 and CZW-3), and 0.033 for WMV-2 (lines W-164 and CZW-3). Plants were either uninoculated or mechanically inoculated with CMV strain Fny (C), ZYMV strain FL (Z), or WMV 2 strain Rob (W) on 14 July and transplanted to the field on 21 July 1993.

b Line CZW-3 contained the coat protein (CP) genes of CMV, ZYMV, and WMV 2; line Z-33 contained the CP gene of ZYMV; line W-164 contained the CP gene of WMV 2; and line C-14 contained the CP gene of CMV. 
experiments, data are given as means of the two experiments.

Comparative virus resistance of plants was assessed by measuring the incidence of systemic virus symptoms over time (Fig. 2). All of the control plants showed systemic symptoms by 39 dpp. Plants of transgenic line CZW-3 did not develop typical systemic symptoms that are induced by CMV, ZYMV, or WMV 2. However, as in the 1993 trial, a number of CZW-3 plants (64\%) developed chlorotic dots which were mainly confined to older leaves. A few CZW-3 plants (6\%) exhibited vein clearing and mosaic foliar symptoms starting $68 \mathrm{dpp}$; this percentage increased to $34 \%$ by the end of the season (88 dpp; Fig. 2). These symptoms suggested the presence of a virus different than those from which the $\mathrm{CP}$ transgenes were derived. This virus was subsequently shown to be PRSV by ELISA (data not shown). Interestingly, plants of transgenic line ZW-20 also showed high levels of resistance. Although localized symptoms consisting of chlorotic dots and blotches, which had been reported in earlier trials $(10,18)$, were observed at the end of the growing season on 21 and $17 \%$ of the ZW-
20 plants, respectively, systemic symptoms did not appear until 26 dpp (Fig. 2). By 88 dpp, $50 \%$ of the ZW-20 plants were systemically infected, with $20 \%$ of them showing CMV-type symptoms consisting of stunting, chlorosis, and downward curling of leaves, and $30 \%$ of them showing PRSV-type symptoms consisting of vein clearing and mosaic. Plants of transgenic line Z-33 showed a 2- to 4-week delay in the onset of disease compared to controls, but all were systemically infected by 68 dpp. Infected Z-33 plants showed mosaic, vein clearing, downward curling of the leaves, chlorosis, or plant stunting.

ELISA was used to correlate symptoms with the presence of specific viruses and to measure the rate of single and mixed infections at 26, 56, and $87 \mathrm{dpp}$. The cumulative ELISA results at the last sampling period, which coincided with the end of the experiment (87 dpp), are summarized in Table 2. Plants of transgenic line CZW-3 had the lowest incidence of virus infection, with only $20 \%$ ELISA-positive plants (Table 2). The three targeted viruses (e.g., CMV, ZYMV, and WMV 2) were detected in leaf tissue with chlorotic dots but not in symptomless green tissue. Of the plants of transgenic line $\mathrm{ZW}-20,51 \%$ reacted positively in ELISA, including $22 \%$ that reacted to CMV. The two potyviruses, ZYMV and WMV 2, were detected in leaf samples of ZW-20 plants that showed chlorotic dots or blotches, whereas CMV was detected in leaf samples of ZW-20 plants with downward curling, chlorosis, and plant stunting. All plants of transgenic line Z-33 reacted positively in ELISA by $87 \mathrm{dpp}$, with WMV 2 predominating in single and mixed infections. CMV was detected in $17 \%$ of the Z-33 plants. Nearly all $(90 \%)$ of the control plants were infected by more than one virus. In contrast, plants of transgenic lines CZW-3, ZW-20, and Z-33 had mixed infections in 5, 22, and $40 \%$ of them, respectively. ELISA also detected contaminating PRSV in approximately $25 \%$ of all plants. PRSV infections were observed late in the season and were apparently introduced from sources outside the test area.

Fruit production was determined by picking fruit at regular intervals and grading them for marketability. Based on the results of nine fruit harvests, plants of transgenic line CZW-3 had the highest production, a total of 1,234 fruit, $95 \%$ of
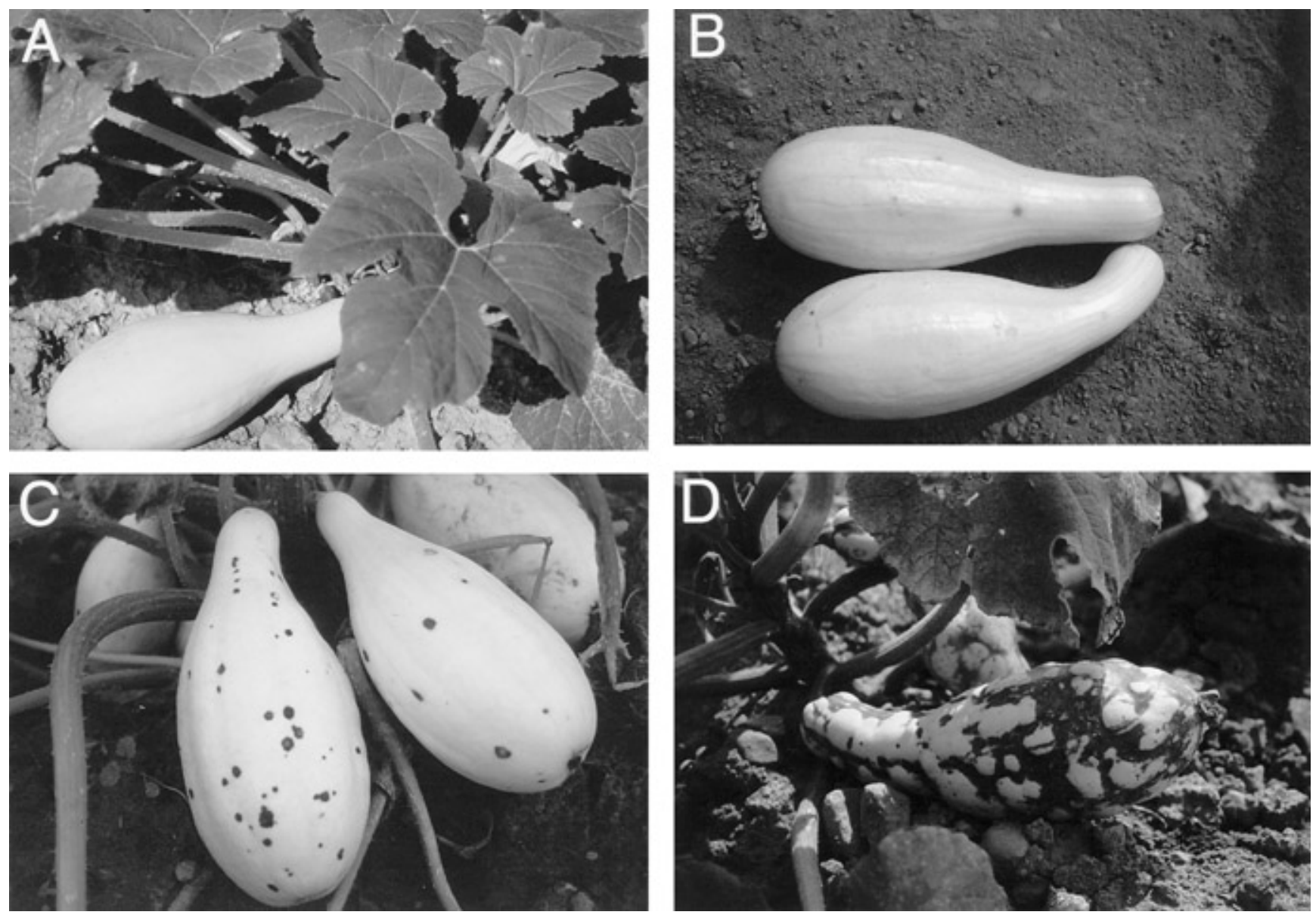

Fig. 1. Analysis of fruit of transgenic and control squash plants exposed to mixed infections by cucumber mosaic cucumovirus (CMV), zucchini yellow mosaic potyvirus (ZYMV), and watermelon mosaic virus 2 potyvirus (WMV 2). (A) Plants of transgenic line CZW-3 containing the coat protein (CP) genes of CMV, ZYMV, and WMV 2 produced fruit with no symptoms; (B) plants of transgenic line ZW-20 containing the CP genes of ZYMV and WMV 2 produced mostly symptomless fruit (bottom) but a few showed green dots (top); (C) plants of transgenic line Z-33 containing the CP gene of ZYMV had symptomatic fruit with numerous green dots; and (D) control plants produced fruit with severe deformation and discoloration. 
which were of marketable quality (Fig. 3). CZW-3 plants averaged 16 marketable fruit (Fig. 1A). A few symptomatic CZW-3 fruit (5\%) were produced late in the season (Fig. 3) when PRSV was detected (Fig. 2). Plants of transgenic line ZW-20 produced a total of 1,030 fruit, $85 \%$ of which were of marketable quality (Fig. 3). ZW-20 plants averaged 12 marketable fruit. Symptomatic ZW-20 fruit developed (Figs. 1B and 3) when the incidence of CMV and PRSV was detectable starting $50 \mathrm{dpp}$ (Fig. 2). Plants of transgenic line Z-33 were much less productive than those of the two trans- genic lines with multiple $\mathrm{CP}$ genes, and produced a total of 679 fruit, of which $66 \%$ were of marketable quality. Z-33 plants averaged 6 marketable fruit. Symptomatic Z-33 fruit (Fig. 1C) were apparent as early as 39 dpp (Fig. 3) due to infections by WMV 2 (Fig. 2). The incidence of infected Z-33 fruit increased thereafter due to coinfections by WMV 2, CMV, and PRSV (Fig. 2). Control plants produced nearly all distorted fruit (Fig. 1D); only 4\% of the 531 fruit were of marketable quality (Fig. 3), which translated to 0.3 marketable fruit per plant.

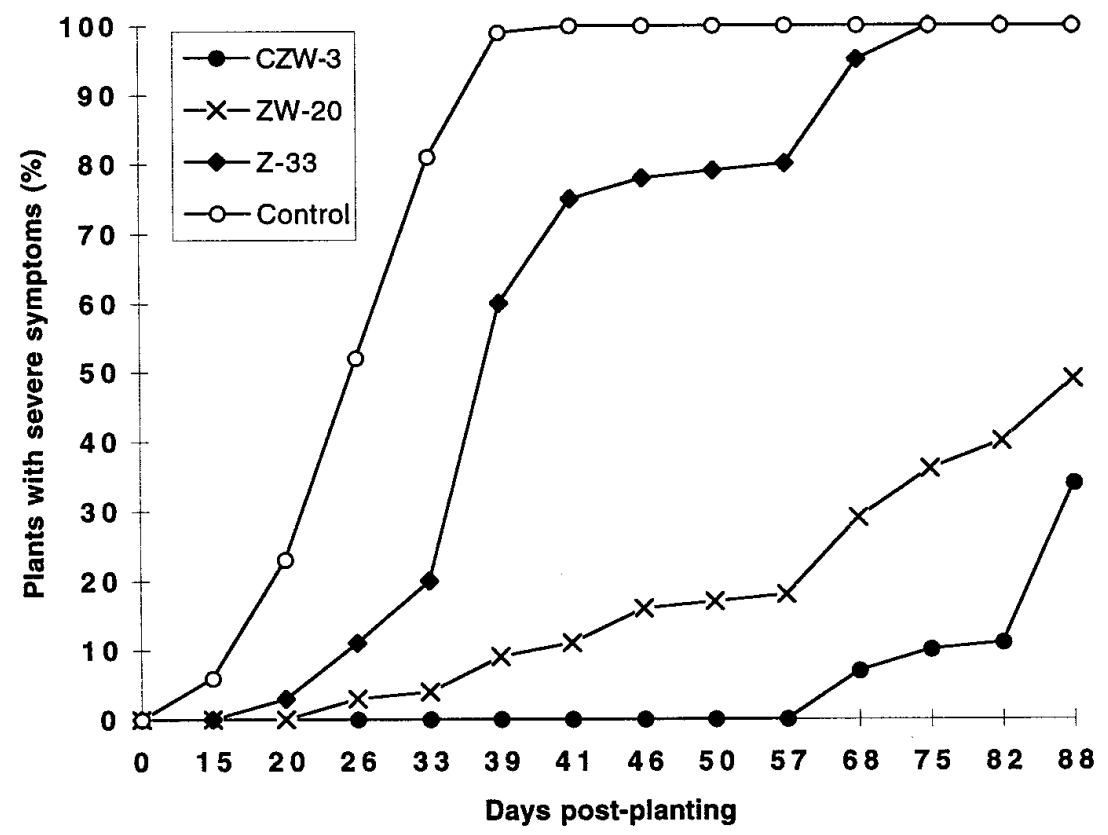

Fig. 2. Disease progress curves on three transgenic squash lines and control $(\bigcirc)$ exposed to mixed infections by cucumber mosaic cucumovirus (CMV), zucchini yellow mosaic potyvirus (ZYMV), and watermelon mosaic virus 2 potyvirus (WMV 2) via aphids in 1995. The transgenic lines were CZW-3, containing the coat protein (CP) genes of CMV, ZYMV, and WMV $2(\bullet)$; ZW-20, containing the CP genes of ZYMV and WMV ( $x$ ); and Z-33, containing the CP gene of ZYMV ( $\square$ ). Data from two separate experiments were pooled because significant differences were not found between the two experiments.
The total weights of marketable fruit produced by each line were also compared. Plants of transgenic lines CZW-3, ZW-20, and Z-33 averaged 5.0, 4.0, and $2.0 \mathrm{~kg}$ of marketable fruit, respectively, whereas control plants averaged $0.1 \mathrm{~kg}$. This represented a 20,60 , and $98 \%$ reduction in yield of marketable fruit for ZW-20, Z-33, and control plants, respectively, compared to CZW-3 plants.

As in the 1993 trial, analysis of the data by ANOVA indicated that the effect of genotype was significant for symptom development, virus incidence, total fruit yield, and yield of marketable fruit $(P<$ $0.001)$. Variations in symptom development, virus detection by ELISA, and fruit yield, as well as blocking, were not significant between the two separate experiments. Analysis of the data by Helmert contrasts indicated that the differences observed among genotypes were significant throughout the season $(P<0.005)$.

To estimate possible profits, a cost-benefit analysis was performed using a model farm with a seeding density of 12,500 plants ha $\mathrm{ha}^{-1}$ and a fruit yield of $25 \mathrm{t} \mathrm{ha}^{-1}$ (20). The profit of CZW-3 was used as a standard to which the other transgenic lines and the control were compared. As described above, marketable yields of $\mathrm{ZW}$ 20, Z-33, and 'Pavo' were 20, 60, and 98\% less, respectively, than that of CZW-3. Cash returns were calculated as expected cash returns minus production and seed costs. Expected cash returns were equal to yield $\times$ net returns $(20)$. With the exception of seed costs, production costs $\left(\$ 3,800 \mathrm{ha}^{-}\right.$ ${ }^{1}$ ) and net returns $\left(\$ 0.35 \mathrm{~kg}^{-1}\right.$ of marketed fruit) were considered to be the same for each line (20). Thus, fruit yield and seed cost (\$600 and $300 \mathrm{ha}^{-1}$ for transgenic and control seeds, respectively) were the only variables. Transgenic line CZW-3 had an estimated cash return per hectare of $\$ 4,350$ $(=\$ 8,750-4,400)$, and ZW-20 an estimated cash return of $\$ 2,600 \quad(=\$ 7,000-$ 4,400). Transgenic line Z-33 did not have

Table 2. Enzyme-linked immunosorbent assay (ELISA) detection of cucumber mosaic cucumovirus (CMV), zucchini yellow mosaic potyvirus (ZYMV), and watermelon mosaic virus 2 potyvirus (WMV 2) in transgenic squash lines after exposure to aphid-vectored inoculations by CMV, ZYMV, and WMV-2 during the 1995 growing season

\begin{tabular}{|c|c|c|c|c|c|c|c|c|c|}
\hline \multirow[b]{2}{*}{ Genotypes $^{\text {b }}$} & \multirow[b]{2}{*}{ No. plants } & \multicolumn{8}{|c|}{ Percent ELISA-positive plants ${ }^{a}$} \\
\hline & & Total & $\mathbf{C}$ & $\mathbf{Z}$ & $\mathbf{W}$ & $\mathbf{C Z}$ & $\mathbf{C W}$ & $\mathbf{Z W}$ & CZW \\
\hline \multicolumn{10}{|c|}{ Transgenic lines } \\
\hline CZW-3 & 73 & 20 & 3 & 7 & 5 & 0 & 0 & 5 & 0 \\
\hline ZW-20 & 72 & 51 & 8 & 15 & 6 & 11 & 0 & 8 & 3 \\
\hline Z-33 & 72 & 100 & 2 & 11 & 47 & 3 & 0 & 25 & 12 \\
\hline \multicolumn{10}{|c|}{ Non-transgenic line } \\
\hline Pavo & 71 & 100 & 2 & 8 & 0 & 3 & 0 & 69 & 18 \\
\hline
\end{tabular}

a Data represent cumulative percent of ELISA-positive plants for CMV (C), ZYMV (Z), WMV 2 (W), CMV + ZYMV (CZ), CMV + WMV 2 (CW),

ZYMV + WMV 2 (ZW), and CMV + ZYMV + WMV 2 (CZW) on 25 September (87 days post transplanting). Infected plants had optical density (OD) $405 \mathrm{~nm}$ readings 5 to 14 times higher than healthy plants $(0.085$ to 0.265 versus 0.016 to 0.024 for CMV, 0.095 to 0.520 versus 0.018 to 0.040 for ZYMV, and 0.095 to 0.350 versus 0.019 to 0.025 for WMV 2) after 60 min substrate hydrolysis. Noninfected transgenic plants had OD $405 \mathrm{~nm}$ values of 0.032 for CMV (line CZW-3), 0.044 for ZYMV (lines CZW-3, ZW-20, and Z-33), and 0.041 for WMV 2 (line ZW-20). Plants were transplanted to the field on 29 June 1995, and subject to aphid inoculations from spreader plants infected with CMV strain Fny, ZYMV strain FL, or WMV 2 strain NY.

${ }^{\mathrm{b}}$ Line CZW-3 contained the coat protein (CP) genes of CMV, ZYMV, and WMV 2; line ZW-20 contained the CP genes of ZYMV and WMV 2; and line Z-33 contained the CP gene of ZYMV. 
cash returns $\left(\$-1,000 \mathrm{ha}^{-1}\right)$, except if the market sale price was high $\left(>\$ 0.44 \mathrm{~kg}^{-1}\right)$. The 'Pavo' control did not provide economical returns (approximately $\$-3,900$ $\mathrm{ha}^{-1}$ ) regardless of the market price.

\section{DISCUSSION}

Our field studies demonstrated that transgenic squash plants that are resistant to all, two, or only one of the targeted viruses (i. e., CMV, ZYMV, and WMV 2) showed a lower incidence of infection and had significantly higher yield of marketable fruit than susceptible control plants. A relative cost-benefit analysis suggested that resistance to even one virus can provide economic benefits. These results are encouraging for the commercial use of virusresistant transgenic squash because it is unlikely that a single cultivar will exhibit resistance to all viruses that pose a threat to squash production.

Our estimated values for profit are not definitive because production costs and expected returns $\left(\$ 0.15\right.$ to $\left.0.55 \mathrm{~kg}^{-1} ; 20\right)$ are highly variable depending on production area, cultural practices, weather conditions, and the market situation. However, they represent reasonable predictions of the comparative profitability of transgenic lines with multiple and single virus resistance. Transgenic line Z-33 provided profits only under relatively high fruit prices. However, the performance of transgenic line Z-33 may have been underestimated in our study because it was an inbred, as opposed to transgenic lines CZW-3 and ZW20, which were hybrids. Previous field data suggested that, for the same type of resistance, hybrids are likely to produce higher yield than inbreds (12).

Our work expands on two previous studies in which plants of transgenic lines CZW-3 and ZW-20 were compared in the field. Clough and Hamm (6) evaluated these two lines following mechanical inoculation with ZYMV and WMV 2. They found that both cultivars performed equally, after taking into account that half of their CZW-3 plants were non-transgenic segregants, and far better than controls. Arce-Ochoa et al. (3) obtained similar results in a field trial in which comparisons were made of the horticultural characteristics of both transgenic lines under conditions where no viruses were introduced. Our results confirm and expand on these findings. We have shown that, while transgenic line CZW-3 performed the best under severe aphid inoculation pressure of all three targeted viruses, the other transgenic lines (ZW-20 and Z-33) performed better than the controls even though they do not possess resistance genes to all the introduced viruses. ELISA also showed that transgenic plants had markedly lower incidences of mixed infections than controls, which would make transgenic plants poorer virus sources for secondary spread.
Our field experiments were designed to simulate natural movement of CMV, ZYMV, and WMV 2 into plantings of transgenic and non-transgenic squash by secondary spread from initially infected susceptible plants. Our results showed that virus-resistant transgenic squash offer some epidemiological benefits. Plants of transgenic lines with single and multiple $\mathrm{CP}$ genes reduced the incidence of mixed infections by CMV, ZYMV, and WMV 2, which should make them relatively poor sources of multiple viruses. Also, ZYMV and WMV 2 were localized to dots or blotches on symptomatic leaves of ZW-20 plants, and CMV, ZYMV, and WMV2 were localized to dots on symptomatic leaves of CZW-3. Virus restriction in the transgenic squash plants expressing multiple CP genes should reduce the probabilities of acquisition by aphids. Indeed, our recent experiments have shown that ZW-20 plants with chlorotic dots or blotches are not effective virus sources for the spread of ZYMV and WMV 2 (13).

Our observations, as well as previous works $(10,18)$, show that transgenic squash CZW-3 and ZW-20 are not immune to infection, because they develop chlorotic dots from which the targeted viruses can be recovered. These chlorotic dots are usually observed in the lower leaves; therefore, the large discrepancies in their occurrence in plants of transgenic line CZW-3 (73 and $64 \%$ ) and the corresponding ELISA-positive reactions ( 6 and 20\%; Tables 1 and 2) are due to the sampling method for ELISA. Leaf tissues were taken from young leaves, which had lower frequencies of chlorotic dots.

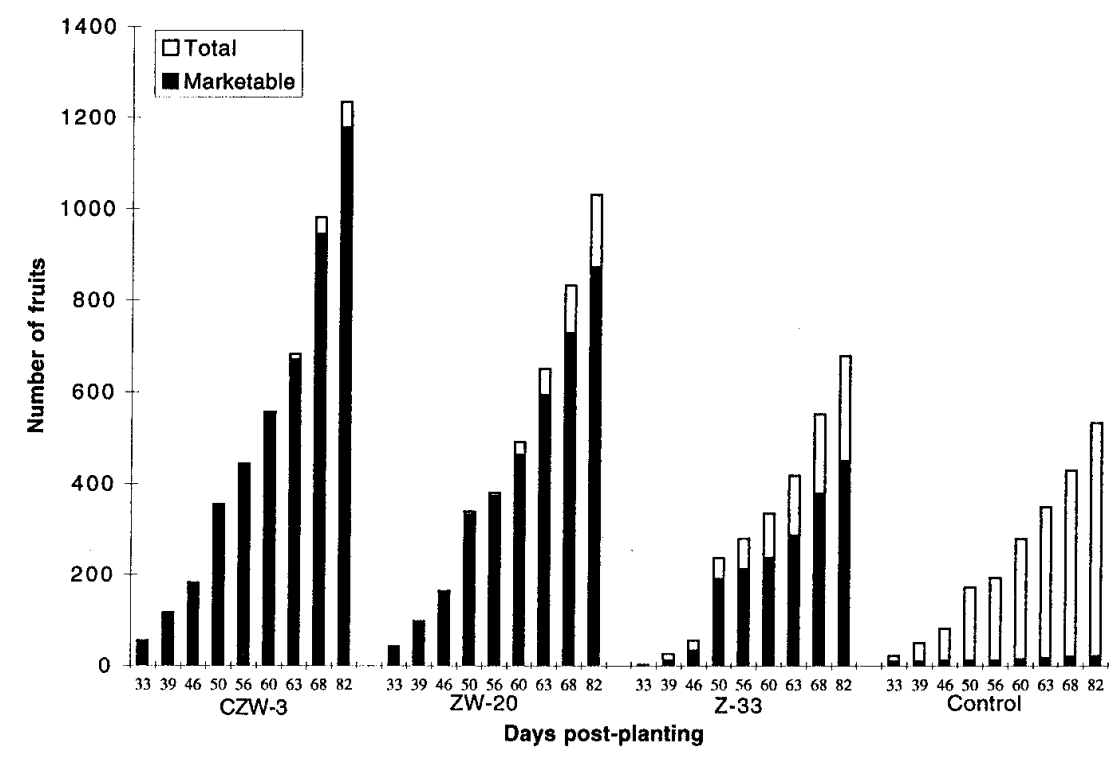

Fig. 3. Number of fruit at nine harvest dates for three transgenic squash lines (CZW-3, ZW-20, and Z-33) and control exposed to mixed infections by cucumber mosaic cucumovirus (CMV), zucchini yellow mosaic potyvirus (ZYMV), and watermelon mosaic virus 2 potyvirus (WMV 2) via aphids in 1995. The total number of fruit (open bar area) and the number of marketable fruit (closed bar area) were distinguished for each genotype. The transgenic lines were CZW-3, containing the coat protein (CP) genes of CMV, ZYMV, and WMV 2; ZW-20, containing the CP genes of ZYMV and WMV; and Z-33, containing the CP gene of ZYMV.
Despite an equal number of mechanically inoculated virus source plants for the three targeted viruses, CMV was transmitted by aphids at a lower rate than ZYMV and WMV 2. The low incidence of CMV is not explained by the lack of appropriate aphid species, because we observed that CMV spread rapidly in nearby cantaloupe fields (12). It is also not explained by the poor transmission rate of the CMV strain used, because strain Fny is highly transmissible by aphids in cantaloupe fields $(4,12)$ and squash plants (4). A plausible reason for the low incidence of CMV in our fields is the lethal effect of CMV on mechanically inoculated control plants. We found that $46 \%$ (46/99) and 18\% (7/38) of the plants mechanically inoculated with CMV died 3 weeks post planting in the 1993 and 1995 trials, respectively. The fact that CMV can be lethal in squash reduces the number of CMV source plants on which aphids can probe relative to the number of ZYMV- and WMV 2-infected plants. Also, CMV-inoculated plants that survived infection were stunted. Thus, the poor condition of the CMV source plants likely made them unsuitable as hosts for aphids, reducing the opportunity for acquisition of CMV and its spread into the fields. Another explanation for the low incidence of CMV may be the higher titer of potyviruses in infected plants compared ZYMV and WMV 2 more likely than CMV to be acquired by aphids.

In the 1995 trial, PRSV was detected by ELISA late in the growing season. This potyvirus was probably introduced from external sources via aphids since it was not to that of CMV (4,21), thus making 
used as inoculum and it is not seed borne. These observations reemphasize the importance of PRSV as a major virus of squash $(5,15,22)$ and the need to develop cultivars with resistance to the four major viruses that cause important losses in squash and cucurbits in general. Given the numerous viruses that affect squash $(5,15,22)$, it seems unlikely that transgenic lines will be developed with resistance to all viruses present in a particular environment. Our data indicate that economic benefits can be obtained even with transgenic lines that are resistant to a limited number of viruses. Surveys to determine which viruses are present in the vicinity of a squash production area should help to predict the level of profits provided by transgenic plants.

\section{ACKNOWLEDGMENTS}

We thank D. Hummer, S. Ecker-Day, V. Souza, P. Malgarini, M. M. Loman, D. Jarecke, and W. Boone for their excellent help; and M. Yepes for critical reading of the manuscript.

\section{LITERATURE CITED}

1. Acord, B. R. 1996. Availability of determination of nonregulated status for squash line genetically engineered for virus resistance. Fed. Regis. 61:33484-33485.

2. Adlerz, W. C., Purcifull, D. E., Simone, G. W., and Hiebert, E. 1983. Zucchini yellow mosaic virus: a pathogen of squash and other cucurbits in Florida. Proc. Fla. State Hortic. Soc. 96:72-74.

3. Arce-Ochoa, J. P., Dainello, F., Pike, L. M., and Drews, D. 1995. Field performance comparison of two transgenic summer squash hybrids to their parental hybrid line. Hort-
Science 30:492-493.

4. Banik, M. T., and Zitter, T. A. 1990. Determination of cucumber mosaic virus titer in muskmelon by enzyme-linked immunosorbent assay and correlation with aphid transmission. Plant Dis. 74:857-859.

5. Blancard, D., Lecoq, H., and Pitrat, M. 1994. Page 29 in: Cucurbit Diseases: Observation, Identification and Control. Wiley and Sons, New York.

6. Clough, G. H., and Hamm, P. B. 1995. Coat protein transgenic resistance to watermelon mosaic and zucchini yellows mosaic virus in squash and cantaloupe. Plant Dis. 79:1107-1109.

7. Davis, R. F., and Mizuki, M. K. 1987. Detection of cucurbit viruses in New Jersey. Plant Dis. 71:40-44.

8. Desbiez, C., and Lecoq, H. 1997. Zucchini yellow mosaic virus. Plant Pathol. 46:809829.

9. Fuchs, M., Ferreira, S., and Gonsalves, D. 1997. Management of virus diseases by classical and engineered protection. Mol. Plant Pathol. On-line 1997/0116fuchs.

10. Fuchs, M., and Gonsalves, D. 1995. Resistance of transgenic hybrid squash ZW-20 expressing the coat protein genes of zucchini yellow mosaic virus and watermelon mosaic virus 2 to mixed infections by both potyviruses. Bio/Technology 13:1466-1473.

11. Fuchs, M., and Gonsalves, D. 1997. Genetic Engineering. Pages 333-368 in: Environmentally Safe Approaches to Crop Disease Control. N. A. Rechcigl and J. E. Rechcigl, eds. CRC Press, Boca Raton, FL.

12. Fuchs, M., McFerson, J. R., Tricoli, D. M., McMaster, J. R., Deng, R. Z., Boeshore, M. L., Reynolds, J. F., Russell, P. F., Quemada, H. D., and Gonsalves, D. 1997. Cantaloupe line CZW-30 containing coat protein genes of cucumber mosaic virus, zucchini yellow mosaic virus, and watermelon mosaic virus 2 is resistant to these three viruses in the field. Mol. Breeding 3:279-290.
13. Klas, F. E., Fuchs, M., and Gonsalves, D. 1994. Spatial analysis as a tool to evaluate virus resistance in a transgenic crop. (Abstr.) Phytopathology 84:1372.

14. Medley, T. L. 1994. Availability of determination of nonregulated status for virus resistant squash. Fed. Regis. 59:64187-64189.

15. Provvidenti, R. 1993. Resistance to viral diseases of cucurbits. Pages 8-43 in: Resistance to Viral Disease of Vegetables: Genetics and Breeding. M. M. Kyle, ed. Timber Press, Portland, OR.

16. Purcifull, D. E., Simone, G. W., Baker, C. A., and Hiebert, E. 1988. Immunodiffusion tests for six viruses that infect cucurbits in Florida. Proc. Fla. State Hortic. Soc. 101:400-403.

17. Sanford, J. C., and Johnston, S. A. 1985. The concept of parasite-derived resistancederiving resistance genes from the parasite's own genome. J. Theor. Biol. 113:395-405.

18. Tricoli, D. M., Carney, K. J., Russell, P. F., McMaster J. R., Groff, D. W., Hadden, K. C., Himmel, P. T., Hubbard, J. P., Boeshore, M. L., and Quemada, H. D. 1995. Field evaluation of transgenic squash containing single or multiple coat protein gene constructs for resistance to cucumber mosaic virus, watermelon mosaic virus 2, and zucchini yellow mosaic virus. Bio/Technology 13:1458-1465.

19. Ullman, D. E., Cho, J. J., and German, T. L. 1991. Occurrence and distribution of cucurbit viruses in the Hawaiian Islands. Plant Dis. 75:367-370.

20. Westberry, G. O., and Mizelle, W. O. 1993. Vegetable production costs and risk rated returns. Coop. Ext. Serv. Univ. Ga. Athens Coll. Agric. Environ. Sci. Agric. Econ. 91-016.

21. Zitter, T. A. 1970. Titers of two virus diseases of celery affecting field spread. (Abstr.) Phytopathology 60:1321.

22. Zitter, T. A., Hopkins, D. L., and Thomas, C. E. 1996. Page 87 in: Compendium of Cucurbit Diseases. American Phytopathological Society, St Paul, MN 